\title{
Impact of Corruption on Economic Growth in Nigeria
}

\author{
Dr. Nwankwo, Odi., FCiB \\ Department of Banking and Finance, Kogi State University, Anyigba Kogi-Nigeria \\ Phone: 08035763229, E-mail: odinwankw02002@yahoo.com
}

\section{Doi:10.5901/mjss.2014.v5n6p41}

\begin{abstract}
Corruption is an ancient practice that has been traced back to pre-biblical time and made itself known in the ancient civilizations of developed and developing countries. This study empirically investigates the impact of corruption on the growth of Nigerian economy using granger causality and regression techniques. The study used gross domestic product (GDP) as a proxy of economic growth and corruption index as a proxy of corruption in our analysis. The study revealed that the level of corruption in Nigeria over the years has significant negative impact on economic growth in Nigeria. The implication of this study is that economy cannot grow fast without zero tolerance in corruption. The study recommended that the policies that will enhance economic growth are expected to be encouraged in reducing corruption and poverty so that the level of economic growth can be improved. And that the activities or programmes of the anti-corruption agencies in Nigeria such as the Economic and Financial Crime Commission (EFCC) and the Independent Corrupt Practices and related Offences Commission (ICPC) should be strengthened.
\end{abstract}

Keywords: Corruption, economic growth, co-integration, EFCC, ICPC

\section{Introduction}

Public debates recently in Nigeria have centred on the increasing rate of corruption resulting from inappropriate public finance planning and implementation mostly in some of the developing countries, Nigeria inclusive which in turn reduce the level of economic growth in the country. Corruption made itself visible when the institution of the government was founded due the behaviour of people appoint or elect to manage the government institutions (Anyanwu, 2002; Idomeh, 2006). Corruption has recently become a major issue in foreign aid and Nigeria nation as a whole. Corruption is an ancient practice that has been traced back to pre-biblical time and made itself known in the ancient civilizations of developed and developing countries. Political and social corruption is not a recent phenomenon that pervades the Nigerian state. Corruption is a social problem that has interested many scholars. Ruzindana (1999) sees corruption in Africa as a problem of routine deviation from affordable standards and norms by public officials and parties with whom they interact. The major concern for inter-nation aid policy during the last five decades has been to improve the living condition for the poor in the poorest countries of the world. But governments in poor countries are also the most corrupt country due to high level of poverty. Treisman (2000) and Paldam (1999) cited in Jens and Odd-Helge (2001) states that the level of GDP per capital holds most of the explanatory power of the various corruption indicators.

Corruption is a disease, which eats into the cultural, political and economic growth of any country and as well destroys the functioning of various organs of the government. Transparently international (2005) opine that "corruption is one of the greatest challenges of the contemporary world which undermines good government, fundamentally distorts public policy, leads to the misallocation of resources harms the private sector development and as well hurts the poor".

The need to study corruption and economic growth in Nigeria has continued to generate passionate commentaries and academic interest due to the level of corruption in the country and its effect on economic growth. In Nigeria corruption is one of the reasons for many unresolved problems that have critically hobbled and reduce development (Ayobolu, 2006). It also remains a long-term major political and economic growth challenge for Nigeria (Sachs, 2007). International centre for economic growth (1999) states that corruption is a canker worm that has eaten deep in the fabric of the nation which ranges from petty corruption to political or systematic corruption. Abiodem (2007) in World Bank studies put corruption at over $\$ 1$ trillion per year accounting for up to $15 \%$ of the Gross Domestic Product of nation like Nigeria. Corruption is a canker worm that has reduced development in all sectors of the economy (EFCC, 2005). Corruption has been the primary reason behind the country difficulties in developing fast (ICPC, 2006). Ribadu, (2003) states that this is the reason why transparency international has consisted rating of Nigeria as one of the top three most corrupt countries in the world. 
In Nigeria, the level of corruption, poor state of our electricity, transport sector, health sector, education sector and communications is the major problem of economic growth and it is a major handicap for doing business in the country. As part of fighting corruption and strengthening the economy, Nigeria government has over the years embark on series of economic growth reform through privatization, banking sector reform, anti-corruption campaigns and establishment of transparent fiscal standards such as ICPC, EFCC etc. The major aim of economic reform in Nigeria is to provide a conducive environment for private investors and FDI to flow (African economic outlook 2011).

\section{Review of Related Literature}

The issue of rising increase in corruption and its effect on economic growth has generated a lot of controversy and debate among academics, economists, bankers, policy makers, researchers and general public in recent times. The effects of corruption on economic growth are still an unresolved issue in both theoretically as well as empirically. This is because the theoretical positions on the corruption are quite diverse and the conventional wisdom is that a large level of corruption in the country is a source of economic instability or stagnation in Nigeria. Some empirical studies did not agree with the conventional wisdom. A few studies reported positive and significant relationship between corruption and economic growth while several others like Rotini, Obasaju, Lawal, and Ise (2013) found no relationship between an increase in corruption and economic growth in real output.

\subsection{Empirical Review}

A few of researchers has discussed the level of corruption on economic growth in both developed and developing countries. Such authors include Abiodum, Elijah and Obayelu (2007) that use descriptive survey and content analysis to investigate the effect of corruption and economic reforms on economic growth and development in Nigeria. It was revealed that there have been significant reductions in the level of corruption in Nigeria through the introduction of the anti-corruption team or instruments. But the study also found negative corruption between the levels of corruption and economic growth, thereby making it difficult for Nigeria to develop fast. This means that corruption in Nigeria reduces economic growth, efficiency and development despite the huge resources in the country. This is also because corruption reduces or create negative image in a nation and as well losses much needed revenue.

Rotini, Obasaju, Lawal and Ise, (2013) used ordinary least square (OLS) and granger causality method to determine the relationship between corruption and economic growth in Nigeria. The study observed that corruption impairs and impacts economic growth. The study fails to establish the level of impact of corruption on economic growth by stating whether it is positive or negative.

Adewale, (2011) investigated the crowding out effects of corruption in Nigeria using parsimonious error correction mechanism and employed experimental research design approach for the data analysis and revealed that there is a negative relationship between corruption and output growth in Nigeria. The implication of this is that Nigeria government should introduce a national re-orientation program to educate people on the crucial need to eradicate corruption in all sectors of Nigeria economy and socio-political system.

Akinpelu, Ogunseye, Bada, and Agbayangi (2013) examined the Socio- Economic Determinants of corruption in Nigeria using co-integration test and vector error correction model. The study discovered that there is a long-run relationship between conception and the social economic variables in Nigeria. This study falls to establish the level of relationship like whether significant positive or negative relationship which has policy implication in the short and long run.

Mnhuda (2013) investigating the relationship between corruption, poverty and economic growth in Nigeria. The study employed regression analysis and granger causality test, it was discovered that there is an existence of cointegration chance tanging a long run causality relationship between corruption, poverty and economic growth in Nigeria.

Ade, Babatude and Awoniyi (2011) in the study of Corruption, foreign direct investment and Economic growth in Nigeria: An empirical investigation employing granger causality test and Ordinary Least Square Method in testing FDI inflow, corruption index, Exchange rate, Inflation rate, GDP for model one. For two, the variables are Gross Domestic Product, Government Expenditure, FDI and Gross fixed capital formation. The OLS result reveals that there is an inverse relationship between FDI inflow and corruption. This means that a large volume of FDI inflow is associated with a low level of corruption in the host countries. Exchange rate depreciation and inflation rate are significant determinations of FDI inflow in Nigeria. Also, there is a significant position. 


\subsection{Theoretical Framework}

\subsubsection{Theories of Corruption and Economic Growth.}

This section highlights some basic theories that have been used to support the effects of corruption on economic growth. Such theories amongst others are:

\subsubsection{A Policy-Oriented Theory of Corruption}

This theory was developed by Teveik, Albert and Charles in 1986, in explaining the role of government in fighting corruption. They states that despite corruption frequent occurrence, government involvement in corruption has undergone surprisingly with its effect of the growth of the economy which needs serious investigation. The theory opine that he high level of corruption in any country whether developed or developing countries will not allow the country's economy to grow and that if the field of administrative corruption is to become more theoretical and less descriptive, it must develop a framework and methodology that will help to measure its effect on economic growth.

\subsubsection{Economic Growth Theory}

This theory was propounded in reactions to the deficiencies in the Solow-Swan growth theory or model by Arrow (1962); Lucas (1988); and Romer (1990). This theory as propounded lay more emphasis on the long-run growth rate of an economy and on the basis of endogenous factors rather than exogenous factors of the neoclassical growth theory. The Solow-Swan model explains that the long-run growth rate of output is based on two basic exogenous variables such as population growth rate and level of corruption in the country. The growth theory emphasizes on technical progress resulting from the rate of capital stock, human capital development, reduction in corruption and investment rate.

\subsection{Policy Implications of the theory}

This theories, believes that economic growth is linked with improvement in productivity and reduction in corruption which ultimately result to a faster pace of innovation and extra investment in human capital. The theory predicted that externalities and spill over on corruption fight from developed countries will help to develop and maintain a competitive advantage in economic growth in Nigeria.

\section{Methodology}

Various definitions of corruption and its relations with economic growth as seen in section one and two above have shown that corruption does the wrong thing instead of the good thing. This is in line with the general saying that wrong thing cannot bring good thing rather it will end up bring bad thing, hence the effect of corruption is assumed to be highly negative in most discussion in the literature while some authors are of the opinion that corruption is positively correlated with economic growth. Based on the above and the nature of this study, the study employs simple econometric models like Augmented Dicker-Fuller test, granger casualty test and co-integration test to investigate the impact of corruption on economic growth in Nigeria.

\subsection{Model Specification}

In $Y_{t}=B_{0 t}-B_{1}$ in $C O R \ldots 1$

Considering the functional notation, the models are specified as followed;

$\mathrm{GDP}=\mathrm{f}(\mathrm{COR}) \ldots 2$

However, the linear function of the above notation is stated as

$\mathrm{GDP}=\mathrm{b}_{0}+\mathrm{b}_{1} \mathrm{COR}+\mathrm{U}_{\mathrm{t}} \ldots 3$

While the log function of the above model is written as

$\log (\mathrm{GDP})=\mathrm{b}_{0}+\mathrm{b}_{1} \log (\mathrm{COR})+\mathrm{U}_{\mathrm{t}} \ldots 4$ 


\subsection{Unit root test}

The Augmented Dickey-Fuller (ADF) formulae were employed to test for stationarity or the existence of unit roots in the data. The test results are as presented below:

Augmented Dickey Fuller Unit Root Test

\begin{tabular}{|c|c|c|c|c|c|}
\hline Series & ADF Test Statistic & $5 \%$ critical values & $10 \%$ critical values & Order & Remarks \\
\hline GDP & -1.783871 & -3.0124 & -2.6461 & $1(1)$ & Stationary \\
\hline COR & -4.680257 & -3.0207 & -2.6504 & $1(1)$ & Stationary \\
\hline
\end{tabular}

E-VIEW 7.0

The empirical tests on unit root test above shows that economic growth proxy by GDP and corruption COR are integrated of order one. They are integrated of the same order; 1(1). From the above tables 1, it was found that ADF Test with trend and intercept indicated that time series are integrated of the same order. The linear combination of series integrated of the same order are said to be cointegrated. The level of their integrations indicates the number of time series have to be differenced before their stationarity is induced. Considering the ADF test statistics at $5 \%$ and10\% critical values, it is observed that test statistics are greater than the critical values. Thus, the series are said to be stationary at that level.

\subsection{Johansen co-integration test for the series; GDP and COR}

\begin{tabular}{|c|c|c|c|c|}
\hline Eigenvalue & Likelihood Ratio & 5 percent critical value & 1 percent critical value & Hypothesized No. of CE(s) \\
\hline 0.352866 & 10.98154 & 15.49471 & 12.45 & None ${ }^{* *}$ \\
\hline 0.483990 & 5.842291 & 3.841466 & 1.34 & At most $1^{\text {** }}$ \\
\hline
\end{tabular}

${ }^{*}(* *)$ denotes rejection of the hypothesis at $5 \%$ significance Level

L.R test indicates 8 cointegrating equation(s) at $5 \%$ significance.

Normalized Cointegrating Coefficients: 1 cointegrating Equation(s)

Judging from the above result, we can agree that there is a long run relationship between the GDP and the explanatory variable; GDP and COR. Firstly, the summary of the Johansen Cointegration Test is shown in the Table above. The model with lag 1 was chosen with the linear deterministic test assumption. Under the Johansen Cointegration Test, there are three cointegrated vectors. In Johansen's Method, the eigenvalue statistic is used to determine whether cointegrated variables exist.

Cointegration is said to exist if the values of computed statistics are significantly different from zero. The Likelihood Ratio is higher than $5 \%$ critical value and the eigenvalues are found as (0.352866 and 0.483990$)$. The Likelihood Ratio of GDP and COR are greater than the critical values at both $5 \%$ and $1 \%$ level of significance. Also, their Eigenvalues are significantly greater than zero. In other words, the null hypothesis of no cointegration among the variables is rejected in at least five equations. The test result shows the existence of a long-run equilibrium relationship in five cointegrating equations at $5 \%$ significance level.

In any case, the existence of a long-run cointegrating equilibrium also provides for short-term fluctuations. In order to straighten out or absolve these fluctuations, an attempt was made to apply the Error Correction Mechanism (ECM).

\subsection{Granger causality test}

\begin{tabular}{l|c|c}
\hline \multicolumn{1}{c}{ Null Hypothesis: Obs } & F-Statistic & Probability \\
\hline GDP does not Granger Cause COR 22 & 2.74957 & 0.0137 \\
COR does not Granger Cause GDP & 0.82907 & 0.3739 \\
\hline
\end{tabular}

Source: Author's calculation 2013 using E-View 7.0

Considering the output of Granger Causality and using 2 and 22 degree of freedom, the F-tabulated value is 2.65 at $5 \%$ level of significance. It is observed from the pair-wise relationship between GDP and COR that the F-statistics is 2.75 while the value for COR and GDP is 0.83 . The estimate shows that 2.75 is greater than 2.65 while 0.83 is less than 2.65 hence, the rejection that GDP does not granger cause COR. This implies that there is one-way causation between GDP and $\mathrm{COR}$ because corruption granger cause slow economic growth but economic growth does not granger cause corruption. 


\subsection{Error Correction Model}

$\begin{aligned} & \text { Dependent Variable: LOG(AT) } \\ & \text { Method: Least Squares } \\ & \text { Sample: } 1997-2010\end{aligned}$
No of observation 14

$\mathrm{R}^{2}=0.689742$

\section{Source: E-views 7.0}

In order to absolve the short-run dynamics of the relationships, the Error Correction Mechanism holds that a negative error correction coefficient is a necessary condition in the model. In this case, the error correction coefficient is -0.365701 . This means that the system corrects its previous period disequilibrium at a speed of $35.57 \%$ annually. Moreover, the sign of error correction coefficient is negative and significant indicating the validity of long run equilibrium relationship between GDP and corruption (COR). More so, it is concluded that the Error Correction Model (ECM) is not a spurious model as the computed $R^{2}$ value of 0.689742 is lower than 1.62 (Durbin Watson Statistics). However, the $\mathrm{R}^{2}$ shows that $68.98 \%$ of the total variations in GDP are accounted for, by the corruption. This means that the level of corruption in Nigeria over the years has significant negative impact on economic growth in Nigeria.

\section{Conclusion and Recommendations}

\subsection{Conclusion}

Nigeria has the potential to build a prosperous economy, reduce poverty significantly and provide the health, education, and infrastructure services its population needs. However, available evidence indicates that these resources have not been judiciously used to meet the need of the population in terms of human capital development because of high level of corruption in the country. The main aim of this study is to examine the impact of corruption on economic growth in Nigerian. The study employed co-integration test, granger causality test and ordinary least square (OLS) method. We used gross domestic product (GDP) as proxy for corruption and corruption index as proxy for corruption. The empirical analysis reveals that there is a long run relationship between the level of corruption and economic growth in Nigeria and that the impact of corruption on economic growth in Nigeria is negative from the ECM result. The implication of this finding is that economy cannot grow fast without zero tolerance in corruption. Finally, the study support previous results in the literature of the effect of corruption on economic growth.

\subsection{Recommendation}

Based on the above findings, the following recommendations are presented;

1. The policies that will enhance economic growth are expected to be encouraged in reducing corruption and poverty so that the level of economic growth can be improved.

2. The activities or programmes of the anti-corruption agencies in Nigeria such as the Economic and Financial Crime Commission (EFCC) and the Independent Corrupt Practices and related Offences Commission (ICPC) should be strengthened.

3. There should be free and fair election in Nigeria so that the honest individuals who would serve as role models will be put elected into leadership positions so as to minimize the negative impact of corruption on economic growth in Nigeria. 


\section{References}

Abiodum, E. O. (2007). The effect of corruption and economic reforms on economic growth and development in Nigeria. Journal of Social Sciences and Finance, 2(1): 15-25

Ade, A. O., Babatude, H. and Awoniyi, M. A. (2011). The relationship between Corruption, Foreign Direct Investment and Economic Growth in Nigeria. An empirical investigation. Journal of Research in International Business and Management, 1(9): 278-292

Adewale, S. B. (2011). The crowding-out effects of corruption in Nigeria: An empirical study. Journal of Business Management and Economics, 2(2): 059-068

African Economic Outlook (2006). Nigeria. African Economic Outlook 2005-2006. Retrieved on the 20th April 2007 on www.oecd.org/africanoutlook

Akinpelu, S., Ogunseye, U., Bada, I. S. and Agbayangi, A. (2013). The socio-economic determinants of corruption in Nigeria. European Journal of Humanities and Social Sciences, 19(1): 1-17

Anyanwu, J. C. (2002). Nigerian Public Finance: Joaneel Publishers, Onitsha

Ayobolu, J. (2006). EFCC, Corruption and the Due Process. Segun Toyin Dawodu, USA

EFCC (2005). Effect of Corruption on Nigeria's Economy. Nigeria EFFC Information Communication Technology Department. Abuja

I.C.P.C (2006). Nigeria and Corruption. Independent Corrupt Practices and Other Related Offences Commission

Idomeh, A. O. (2006). Public Finance: A Modern Approach Head-Mark Publishers Ltd, Benin City.

Integration." Brookings Papers on Economic Activity,1-118.

International Center for Economic Growth (1999). ICEG Information Brief 6, Causes and Effects of Corruption, Nairobi, 1999.

Jens, C. A. and Odd-Helge, F. (2001). Corruption: A Review of Contemporary Research. Transparency International Working Paper.

Lucas, R. E (1988). On the mechanics of Economic Development. Journal of Monetary Economics, 2(1); 1-9

Muhuda, P. (2013). Investigating the relationship among corruption, Poverty and economic growth in Nigeria. Journal of Banking, 4(2): 15-30

Paldam, M. (1999a): The big pattern of corruption: Economics, culture and the seesaw dynamics, Department of Economics, University of Aarhus, (Working Paper no. 1999-11).

Paldam, M. (1999b): "Corruption and religion. Adding to the economic model", Department of Economics, University of Aarhus, unpublished mimeo.

Ribadu, M. N (2003). Economic Crime and Corruption in Nigeria: the Causes, Effects, and efforts aimed at combating these vices in Nigeria. Paper presented at the Monaco World Summit 5th International Summit on Transnational Crime Monte Carlo 23rd and 24th October 2003

Ribadu, M.N. (2006) Nigeria's Struggle with Corruption. Paper presented to US Congressional House Committee on International Development, Washington, DC on May 18. Retrieved on November 25, 2013 from http://ippanigeria.org/efcc.pdf.

Romer, P. (1986). "Increasing Returns and Long Run Growth." Journal of Political Economy, vol. 94, No. 2,1002-1037.

Rotini, E. M., Obasaju, B., Lawal, A. D. and Ise, O. J. (2013). Analysis of Corruption and Economic Growth in Nigeria. Afro Asian Journal of Social Sciences, 4(4.2): 1-19

Sachs. G. (2007). "Corruption Remains Nigeria's Long Term Challenge". The Daily Independent Newspapers Tuesday, 24 April 2007

Sanusi, L. S. (2013). Corruption, insecurity threaten economic growth in Nigeria. Punch newsonline. March 2013

Tevei, F. N., Albert, C. P. and Charles, S. (1986). A policy-oriented theory of corruption. American Political Science Review, published in United State of America. University of Michigan Flint.

Transparency International (2005). Corruption Index. Various series

Treisman, Daniel (2000), The causes of corruption: A cross-national study. Journal of Public Economics, Volume 76, pp. $399-457$.

United Nations (2001). UN Global Programme Against Corruption. Anti-Corruption toolkit. www.odcep.org/pdf/crime/toolkit/fitof7.pdf www. freedomhouse.org.

www.transparency.org/speeches/pe. 